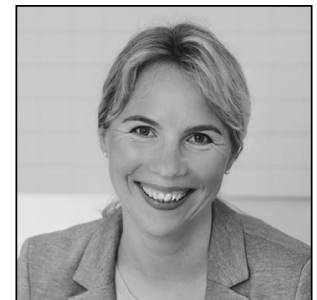

Karin Sein

Professor of Civil Law

University of Tartu

\title{
The Applicability of the Digital Content Directive and Sales of Goods Directive to Goods with Digital Elements
}

\section{Introduction}

There is an ongoing trend to develop more and more inter-connected or 'smart' consumer goods such as smart cars, smartphones, smart watches, wearables, laptops, or smart devices such as Amazon Echo. It is characteristic to these goods that they either contain digital content (e.g. software) or use digital services for certain of their functions (e.g. the navigation system of a smart car). Adoption of the new Digital Content Directive ${ }^{*_{2}}$ (hereinafter DCD) and Sales of Goods Directive ${ }^{*}$ (hereinafter SGD) in late spring 2019 has raised a question as to the delimitation of the scopes of the directives: are 'smart goods' - or 'goods with digital elements' as the directives ${ }^{*}$ call them - subject to the Digital Content Directive, instead to the new Sales of Goods Directive, or possibly to both? The question is evident as, for example, a smartphone is a good, i.e. a tangible object ${ }^{* 5}$, which suggests that it should lie within the scope of the SGD. The operating system of it is, however, digital content, which leads to the applicability of the DCD. ${ }^{* 6}$

This delineation question has emerged due to the approach used in the Digital Content Directive, which creates a new contract law regime for a specific legal object: digital content/service. As this specific legal object can be integrated into another legal object (a good) or inter-connected with it, one component of a product - digital content - can be subject to a legal regime different from that applicable to the rest of the product. ${ }^{*} 7$ Traditionally, the civil codes in European countries as well as the European contract law instruments are based on specific contract types (characterised by specific obligations of the parties) and

\footnotetext{
The research leading to this article was supported by the Estonian Research Council's grant PRG124.

2 Directive (EU) 2019/770 of the European Parliament and of the Council of 20 May 2019 on certain aspects concerning contracts for the supply of digital content and digital services [2019] OJ L 136/1.

3 Directive (EU) 2019/771 of the European Parliament and of the Council of 20 May 2019 on certain aspects concerning contracts for the sale of goods [2019] OJ L 136/28.

4 See SGD art 2(5) and DCD art 2(3).

5 See SGD art 2(5).

6 See DCD art 2(1) and 3(1).

7 Karin Sein, 'What Rules Should Apply to Smart Consumer Goods? Goods with Embedded Digital Content in the Borderland Between the Digital Content Directive and “Normal” Contract Law' (2017) 8 (2) JIPITEC 97; Karin Sein and Gerald Spindler, 'The New Directive on Contracts for the Supply of Digital Content and Digital Services - Scope of Application and Trader's Obligation to Supply - Part 1' (2019) 15(3) ERCL 269. - DOI: https://doi.org/10.1515/ercl-2019-0016.
} 
not on the objects of the contracts. As stated by Professor Florian Faust, we have sales contracts, rental contracts, and contracts on services, not contracts on cars, contracts on fridges, or contracts on Kinder Surprise eggs. ${ }^{*}$ Yet, after the adoption of the DCD, we do have specific consumer contract law on digital Kinder Surprise eggs - be it sales, rental, or creation of them. Surely, the Digital Content Directive has raised the level of consumer protection in the European Union, setting forth mandatory consumer contract norms for all types of digital-content-related consumer contracts. On the negative side, however, it has created a situation where determination of the scopes of the directives has become very complicated, concentrating the problems exactly in the area of goods with digital elements.

The most complicated one of these problems involves the so-called multi-party situations - that is, situations of goods with ancillary digital services (such as smart TVs including Netflix and YouTube applications, smart cars with digital navigation systems, or app-controllable Christmas lights) where the consumer buys the tangible good from a seller but concludes an additional licensing contract with the digital content provider for using the digital services. ${ }^{*}$ Do problems with Netflix entitle the consumer to terminate the sales contract or to a reduction in the price of a new smart TV? And what about apps not functioning properly on the smartphone or the navigation system of a smart car?

\section{Delineation between the DCD and SGD in cases of goods with digital elements}

\subsection{The notion of goods with digital elements and the main policy choice}

The delineation between the DCD and SGD is defined in Article 3(4) DCD and Article 3(3) SGD and the corresponding recitals. ${ }^{*} 10$ According to these provisions, goods with digital elements are within the scope of the new Sales of Goods Directive. 'Digital elements' within the meaning of the directive include both embedded digital content and ancillary digital services: according to Article 2(5) SGD and the corresponding Article 2(3) DCD, goods with digital elements are defined as tangible movable items that incorporate, or are interconnected with, digital content or a digital service in such a way that the absence of that digital content or digital service would prevent the goods from performing their functions. These goods fall within the scope of the SGD (Article 3(3) SGD) and are exempted from the scope of the DCD. ${ }^{* 11}$

Here we see that the main policy solution of the directives has been to make the seller of the good - and not the digital service provider - liable for defects both in hardware and embedded digital content and in the inter-connected digital services. ${ }^{{ }^{1} 2}$ From the perspective of a normal consumer, subjecting goods with embedded digital content such as firmware of a computer to the consumer sales rules makes perfect sense: a smart good is still a good, even if it's smart. If the anti-lock software of a car brake does not function, this clearly constitutes a lack of conformity of the car and the car's seller should be liable for it even if he has not produced the software himself. The situation here is no different from a situation where a lack of conformity

8 Florian Faust, Digitale Wirtschaft - Analoges Recht. Braucht das BGB ein Update? Gutachten zum 71. Juristentag (C.H. Beck 2016) 9.

9 On the situation before the adoption of the new directives and suggestion to employ the concept of connected contracts, see Piia Kalamees and Karin Sein, 'Connected Consumer Goods: Who Is Liable for Defects in the Ancillary Digital Service?' (2019) 8(1) EuCML 13ff; Ivo Bach, 'Server- und Infrastrukturzugänglichkeit als Qualität' in Martin Schmidt-Kessel and Malte Kramme (eds), Geschäftsmodelle in der digitalen Welt (JWV2017) 233ff and three possible regulation models suggested by C Wendehorst, 'Hybride Produkte und hybrider Vertrieb. Sind die Richtlinienentwürfe vom 9. Dezember 2015 fit für den digitalen Binnenmarkt?' in Christiane Wendehorst and Brigitta Zöchling-Jud (eds), Ein neues Vertragsrecht für den digitalen Binnenmarkt - Zu den Richtlinienvorschlägen der Europäischen Kommission vom Dezember 2015 (MANZ 2016) $60 \mathrm{ff}$.

10 Recitals 21 and 22 DCD and recitals 13, 15, and 16 SGD.

11 Article 3(4) DCD provides: 'This Directive shall not apply to digital content or digital services which are incorporated in or inter-connected with goods within the meaning of point (3) of Article 2, and which are provided with the goods under a sales contract concerning those goods, irrespective of whether such digital content or digital service is supplied by the seller or by a third party'. Also see Klaus Tonner, 'Die EU-Warenkauf-Richtlinie: auf dem Wege zur Regelung langlebiger Waren mit digitalen Elementen' (2019) VuR 367.

12 Sein and Spindler (n 7); Dirk Staudenmayer, 'Kauf von Waren mit digitalen Elementen - Die Richtlinie zum Warenkauf' (2019) NJW 2889. 
is caused by another (a non-digital) part of the good: the seller cannot escape liability just because the defective part of the product sold was manufactured by someone else. ${ }^{*} 13$

While it is more or less evident what constitutes embedded digital content - broadly speaking, it is software that is integrated into the good - the notion of inter-connected or ancillary digital services needs a bit more explanation. The recitals of the Sales of Goods Directive cite the following examples of such interconnected digital services: applications of a smart TV, standardised pre-installed applications of a smartphone, software-as-a-service solutions offered in a cloud computing environment, the continuous supply of traffic data in a navigation system, and the continuous supply of individually adapted training plans in the case of a smart watch. ${ }^{*} 14$ In these cases, it is also usually not the seller of the good but rather a third party (a digital content provider, often a software producer) who is providing the digital services to the consumer. However, here the consumer often concludes a separate licence agreement with the digital service provider and sometimes also pays a fee for these services.

Yet the point of departure for the directives is that the seller of the good is liable also for the defects of such ancillary/inter-connected digital services, provided that two cumulative conditions are met: a) the digital service is inter-connected with the good in such a way that the absence of that digital service would prevent the good from performing its functions (Article 2(5)(b) SGD) and b) the digital service is provided with the good under the sales contract (Article 3(3) SGD). The following subsections analyse these two preconditions more closely.

\subsection{Condition 1: Absence of the ancillary digital service would prevent the good from performing its functions}

The first condition for the seller's liability involves the functionality of the good: whether or not the good is able to perform its functions without the digital service. It should be noted that the directive does not require that 'main functions' of the good be affected: ${ }^{*}{ }^{15}$ defective performance of any functions of the good is sufficient. The first question is how to determine the functions of the smart good, as certain functionality (for example, using a YouTube application on a smart TV) presupposes the existence of a digital service.

In the first step, must-have functions of the smart good are determined by the contract (i.e. subjective conformity criteria). According to Article 6(a) SGD and Article 6(5) CRD, this depends on the pre-contractual information on the good as well as the contract provisions. If the smart TV is advertised on the home page of the seller as having 'webOS 3.5', 'Alexa Built-in' and 'Google Assistant integrated', then the seller is liable for the operating system as well as for the functioning of Alexa and the Google Assistant service. Regarding Netflix, the same advertisement states: 'Smart functionality gives you access to your favorite apps and content' and 'Internet connection and Netflix subscription are required'. Hence, the seller is liable only for Netflix connectivity and not for the functioning of Netflix itself.

Similarly, where an advertisement for a Nokia smartphone declares that 'Android One ensures that your phone keeps on getting better with time thanks to 2 years of monthly software updates and two free Android number updates, with Google Android ai', then the seller is liable not only for a certain operating system but also for the promised updates (Article 6(d) SGD). ${ }^{*} 16$

In the second step, these contractual functionality agreements must be tested against the objective conformity criteria; ie one must ask what kinds of functions are normal in a smart good of the same type that the consumer may reasonably expect (Article 7(1) SGD) and whether the contractually agreed functionality deviates from them. Application of the objective functionality test here is complicated, however, as digital products are developing and changing very rapidly. This makes development of objective conformity

\footnotetext{
This argument is also brought out by Staudenmayer (n 12) 2889.

Recitals 14 and 15 SGD.

15 See $\mathrm{n} 13$ of the Commission's Proposal of the SGD, which still used the notion 'main functions'. Moreover, defining main functions in the case of a smart good (or indeed in the case of many smart goods) is often complicated as well: is only the possibility of making phone calls the main function of the smartphone or, rather, the possibility of using the Internet? See Sein (n 7) 98.

16 On the updating obligation of the seller, see Staudenmayer (n 12) 2890-2891; Christiane Wendehorst, Aktualisierungen und Andere digitale Dauerleistungen in: Johannes Stabentheiner, Christiane Wendehorst, Brigitta Zöchling-Jud (Hrgs), Das neue europäische Gewährleistungsrecht: zu den Richtlinien (EU) 2019/771 über den Warenkauf sowie (EU) 2019/770 über digitale Inhalte und digitale Dienstleistungen (Manz 2019) 120 et seq.
} 
standards in case law nearly impossible: ${ }^{* 17}$ it is not easy to determine which functions a reasonable consumer may expect from a smart car, a smart TV, or a smart fridge. The same problem arises with contractually promised updates, which under Article 7(3) SGD must not stay below the standard of updates that can be reasonably expected by the consumer under the objective conformity criteria. ${ }^{*}{ }^{*}$ It is hard to imagine that case law could develop unified standards as to how a reasonably expected number of updates should be determined.

\subsection{An inter-connected digital service provided with the good under the sales contract}

The second condition for the seller's liability for an inter-connected digital service is that the digital service be 'provided with the good under the sales contract" ${ }^{* 19}$, or - put simply - that the good and the digital service be 'sold together'. Article 3(3) SGD provides an interpretation rule in case of doubt as to whether the supply of an inter-connected digital service forms part of the sales contract or not: the digital service shall be presumed to be covered by the sales contract. Putting the first and the second condition together, we get a legal presumption that the seller of the smart good is liable not only for the tangible good and embedded digital software but also for the inter-connected digital services even if the consumer concludes an additional licensing contract with the digital service provider in order to benefit from the digital service. ${ }^{{ }^{2} 0}$ Carvalho brings up an example wherein the consumer buys a car with an already installed GPS application: here, also the GPS application (including later updates promised by the seller) is covered by the sales contract and thus subject to the SGD. ${ }^{*}{ }^{21}$

At first glance, this seems to create a rather harsh liability regime for the sellers, who often do not have any control over the actions of the digital content provider. However, a deeper look at the recitals of the directives shows that there is much room left for party autonomy, with a consequence that exactly the opposite might become true in practice.

First, recital 15 SGD stresses that whether or not an inter-connected digital service forms part of the sales contract depends on the content of the sales contract. Moreover, if the consumer concludes a contract for the supply of digital content or a digital service that does not form part of the contract pertaining to the sale of goods with digital elements, that contract should be considered to be separate from the contract for the sale of the goods, even if the seller acts as an intermediary of that second contract with a third-party supplier, and could fall within the scope of the DCD. ${ }^{* 22}$ Again in the example brought up by Carvalho, if the consumer buys a car with no GPS application installed and then 'buys' the latest version of a GPS application over the Internet, there are two contracts, one (on the car) covered by the SGD and the other (for the GPS application) by the DCD. ${ }^{* 3}$ Recital 15 of the DCD also cites an easily understandable example where the consumer downloads a game application from an app store onto a smartphone: here the contract for the supply of the game application is separate from the contract for the sale of the smartphone itself. Consequently, the SGD is applicable only to the sales contract related to the smartphone, while the supply of the game application could fall under the DCD, if the conditions of that directive are met. I see no objections to this solution: clearly, a local electronics shop selling a smartphone should not be liable for apps downloaded later under a separate contract and potentially against a separate fee. Just one argument: the seller has no opportunity to control or assess at the time of the delivery of the smartphone what kind of apps the consumer decides to download and which risks are associated with them. ${ }^{* 24}$

17 See Michael Grünberger, 'Verträge über digitale Güter' (2018) 218 AcP 259. - DOI: https://doi.org/10.1628/acp-2018-0011.

18 Karin Sein and Gerald Spindler, 'The New Directive on Contracts for Supply of Digital Content and Digital Services - Conformity Criteria, Remedies and Modifications - Part 2' (2019) 15(4) ERCL 370. - DOI: https://doi.org/10.1515/ercl-2019-0022.

19 See SGD art 3(3).

20 Recital 15 SGD.

21 Jorge Morais Carvalho, 'Sale of Goods and Supply of Digital Content and Digital Services - Overview of Directives 2019/770 and 2019/771' (2019) 8(5) EuCML 197.

22 Recital 16 SGD

23 See Carvalho (n 21) 197.

24 The situation would be different for pre-installed apps as they should be considered sold and delivered together with the phone itself. In this sense, see also Carvalho (n 21) 197. 
However, the story gets more complicated with the other example cited in recital 16 SGD. The recital describes a situation where it is expressly agreed that the consumer buys a smartphone without a specific operating system and the consumer subsequently concludes a contract for the supply of an operating system from a third party. According to the recital, in such a case the supply of the separately bought operating system would likewise not form part of the sales contract. Therefore, it would not fall within the scope of the SGD but could fall within the scope of the DCD, if the conditions of the DCD are met. This shows that whether and to what extent the sale of, for example, a smartphone falls within the scope of the SGD and, consequently, whether and to what extent the seller is liable for the operating system of the phone depend very much on the content of the sales contract. The directives thus allow for business models where sellers sell only the hardware part of the good and lead the consumer to conclude a licensing contract with a separate digital content provider after the delivery. Such models already exist for goods such as smart cars ${ }^{*} 25$ but can be - and are - developed also for other goods with digital elements.

For example, if the seller of a smartphone expressly provides in the sales contract that it does not supply the operating system or the Google Assistant service and the consumer has to obtain it separately from Google, then the seller's liability for these digital services is excluded even if a normal consumer may usually expect the seller to be liable for the whole smartphone, including the operating system. The same would be true for a situation where the pre-contractual information on the smartphone (which will become part of the sales contract under Article 6(5) $\mathrm{CRD}^{{ }^{*} 26}$ ) contains a statement 'Manage your life with the dedicated Google Assistant button - requires a separate subscription with Google'. The example in recital 16 SGD of the operating system of a smartphone shows that express agreement in the sales contract may override reasonable consumer expectations: a normal consumer would usually expect that he is not buying only the plastic or metal case of the smartphone or smart TV but also its operating system, as the plastic/metal case is totally non-functional without the operating system. ${ }^{*}{ }^{27}$ Furthermore, a clause excluding the liability of the seller for an operating system of a smartphone cannot be declared unfair and non-binding under the Unfair Terms Directive ${ }^{* 28}$, as it reflects mandatory contract law provisions and is thus exempted from the scope of the Unfair Terms Directive. ${ }^{* 29}$

In order to protect the reasonable expectations of the consumer, the courts should set high standards for 'express agreement' excluding the liability of the seller for the inter-connected digital service, especially in cases where such exclusion would come as a surprise for a reasonable consumer. ${ }^{*}{ }^{30}$ Although "express agreement' within the meaning of recital 16 SGD is probably something less than 'expressly and separately accepting the deviation' within the meaning of Article 7(5) SGD, just declaring the seller not liable for the operating system in the standard terms and conditions should not, in my view, meet the test of 'expressly'. Similarly, von Westphalen has argued, within the context of the proposal for the SGD, that the requirement of 'expressly accepted' calls for more than simply taking note of the content of general terms of contract; rather, it requires an individually negotiated contract clause. ${ }^{*}{ }^{11}$ In any case, we must avoid a solution where the consumer is left without any legal protection. If the consumer has remedies only against the digital content provider (e.g. Google) for a defective operating system under the DCD, then exercising them against big digital players outside the European Union often proves to be impossible due to practical hurdles. Moreover, even if the liability of the digital content provider were to be established, using termination or price reduction against him would bring nothing to the consumer as the digital content provider has received no

25 E.g. the Mercedes MeConnect service, at <www.me.mercedes-benz.com/passengercars/being-an-owner/mercedes-meconnect/mercedes-me-connect-services.module.html>.

26 Directive 2011/83/EU of the European Parliament and of the Council of 25 October 2011 on consumer rights, amending Council Directive 93/13/EEC and Directive 1999/44/EC of the European Parliament and of the Council and repealing Council Directive 85/577/EEC and Directive 97/7/EC of the European Parliament and of the Council [2011] OJ L 304/64.

27 In this sense, see also Klaus Tonner, 'Die EU-Warenkauf-Richtlinie: auf dem Wege zur Regelung langlebiger Waren mit digitalen Elementen' (2019) VuR 367. Another example would be a washing machine where the washing programmes are stored in a cloud of a digital content provider. See Christiane Wendehorst, 'Hybride Produkte und hybrider Vertrieb. Sind die Richtlinienentwürfe vom 9. Dezember 2015 fit für den digitalen Binnenmarkt?' in Christiane Wendehorst and Brigitta Zöchling-Jud (eds), Ein neues Vertragsrecht für den digitalen Binnenmarkt - Zu den Richtlinienvorschlägen der Europäischen Kommission vom Dezember 2015 (MANZ 2016) 54.

28 Council Directive 93/13/EEC of 5 April 1993 on unfair terms in consumer contracts [1993] OJ L 95/29.

29 Article 1(2) of the Unfair Contract Terms Directive.

$30 \quad$ See Sein and Spindler (n 7) 19.

31 Friedrich Graf von Westphalen, 'Some Thoughts on the Proposed Directive on Certain Aspects Concerning Contracts for the Sales of Goods' (2018) 7(2) EuCML 70. 
payment from the consumer, so there is nothing that the consumer could claim back from the digital content provider under the DCD.

\section{Smart goods with free and open-source software as a digital element}

The situation becomes even more complicated in cases where the 'digital element' of the good (e.g. the operating system of a smart TV or of a smartphone) is free and open-source software. ${ }^{* 32}$ Recall that recital 16 SGD allows express agreement that the digital element is not part of the sales contract but could be subject to the DCD if the conditions for its applicability are met. However, free and open-source software ${ }^{*} 33$ is excluded from the scope of the DCD if the consumer does not pay a price and the personal data provided by the consumer are exclusively processed by the trader for the purpose of improving the security, compatibility, or interoperability of that specific software (Article 3(5)f DCD). In these cases, the 'separately bought' digital content does not even fall within the scope of the $\mathrm{DCD}^{*} 34$, with the result that the seller is not liable for the digital content under the SGD and the digital content/service provider too is not liable for it under the DCD.

While the Android OS - although operating on an open-source model ${ }^{*} 35$ - most probably is not excluded from the scope of the DCD as Google does not process the personal data exclusively for purposes of improving the security, compatibility, or interoperability of that specific software ${ }^{*} 36$, the situation might be different for other digital elements. It could therefore happen that in certain cases consumers will be even worse off after the transposition of the directives: whereas currently the courts would tend to view a smartphone with a defective operating system as a defective good also in cases where the operating system is based on free and open-source software, it is possible that under the directives consumers can be left without any remedies whatsoever. If the seller has made clear in the contract that he would be liable only for the hardware of the phone and not for the operating system, as recital 16 SGD allows, then the consumer has no remedies against the operating system provider since free and open software does not fall within the scope of the DCD.

\section{Legal consequences of 'digital elements' falling under the Sales of Goods Directive}

This section analyses the legal consequences for the seller in cases where the digital elements of the good sold fall within the scope of the SGD. First, of course, the seller becomes generally liable for the good, including the obligation to update. ${ }^{*} 7$ But subjecting digital elements of the good to the SGD has other specific legal consequences also, starting with the fact that assessment of their conformity has to be carried out in accordance with the SGD and not the DCD rules. Frankly, it is not easy to explain why conformity of a digital service should be assessed differently just because it is inter-connected with a good. Application of the Sales of Goods Directive to the inter-connected digital service would mean, for example, that the principles of privacy by design and by default as objective conformity criteria are not applicable. This can be illustrated by way of practical example: if a consumer buys a text processing software that violates his privacy, that would be considered a lack of conformity under the $\mathrm{DCD}^{*} 38$ with the consequence that in

32 For in-depth material on open-source software, see Till Jaeger and Axel Metzger, Open Source Software. Rechtliche Rahmenbedingungen der Freien Software (5th edn, C.H. Beck 2020).

33 Recital 12 DCD defines this as software where the source code is openly shared and users can freely access, use, modify, and redistribute the software or modified versions thereof.

34 This legal relationship is subject to the applicable national law - which may allow for agreements detrimental to consumers.

35 See <https://source.android.com/>.

36 See Google's Privacy Terms, stating that they use data to 'build better services', 'maintain \& improve our services', 'develop new services', 'provide personalized services, including content and ads', and 'measure performance'. See <https://www. gstatic.com/policies/privacy/pdf/20191015/9ad23b47/google_privacy_policy_en_eu.pdf>.

37 Articles 10(1) and 7(3) SGD.

38 Recital 48 DCD. Applying 'privacy by design' and 'privacy by default' as objective conformity criteria in the DCD was suggested by the European Law Institute; see 'Statement on the European Commission's proposed directive on the supply of digital content to consumers' COM (2015) 634 final. 
serious cases the consumer can terminate the contract and claim back the amount paid for the software. However, if his new smart TV would be found spying on him, then this is not expressis verbis considered a lack of conformity as there is no recital in the SGD comparable to recital 48 of the DCD - although one can surely argue that such a good is not in line with the consumer's reasonable expectations under Article 7(1) d SGD and thereby reach the same result.

In contrast against the maximum harmonisation DCD, which forbids any notification obligation in the national law ${ }^{*} 39$, Article 12 SGD leaves the notification obligation to the discretion of the member states. Thus, if the inter-connected digital service is subject to the SGD, in some member states the consumer may exercise remedies only if having notified of the defect. ${ }^{*} 40$ This creates legal uncertainty especially in crossborder situations as neither consumers nor traders are sure as to whether the possibility of exercise of the consumer's remedies in cases of defective smart goods depends on a previous notification or not.

There are also other options left to the member states that may create different treatment of digital elements of a smart good under different national laws. ${ }^{* 1}$ For example, Article 10(6) SGD allows member states to foresee that, in the case of second-hand goods, the seller and the consumer can agree to a shorter liability period than otherwise applicable, provided that said shorter period is not less than one year. It is important to bear in mind that Article 10(6) SGD refers also to Article 1O(2) SGD, meaning that derogations are possible also for the continuous digital services (e.g. an app for a fitness tracker or a car's navigation system). The member states also have an option to foresee longer liability periods than two years ${ }^{*} 42$ or to apply the doctrine of hidden defects (vices cacher). ${ }^{*} 43$

If goods rules are applicable to the embedded digital content / ancillary digital services, then the trader has no right to modifications under Article 19 DCD. ${ }^{*}{ }^{4}$ Consequently, if the app of a fitness tracker falls under the goods rules, the trader is obliged to deliver updates under Article 7(3) SGD but is not entitled to make modifications to the app. However, here the member states might provide for such a rule in national law.

If digital elements are subject to the Sales of Goods Directive, then the seller may also face a longer reversal of the burden of proof, as the member states are allowed to prolong it to up to 2 years. ${ }^{*} 45$ True, this would apply only to the embedded digital content and not to ancillary digital services (i.e. where the sales contract provides for the continuous supply of the digital content or digital service over a period of time), because for the latter there is a different rule, stating that the relevant period is the whole contract period. ${ }^{*} 6$

Finally, in order to ensure a uniform starting point for the liability periods - for the physical component as well as for the digital element of the good - the liability period and the period of the reversed burden of proof start upon delivery of the digital content (and not on the earlier delivery of the good itself) also for defects in hardware. ${ }^{*} 47$ Recital 39 SGD explains that the seller should also make the digital content or digital service available or accessible to the consumer in such a way that the digital content or digital service, or any suitable means for downloading or accessing it, has reached the sphere of the consumer and no further

39 Recital 11 DCD.

40 Estonian law, for example, obliges consumers to notify the seller within 2 months after they have discovered the defect. On that, see Paul Varul, Irene Kull, Villu Kõve, Martin Käerdi, and Karin Sein, Võlaõigusseadus II. Kommenteeritud väljaanne (Juura 2019) 114.

41 See also on this Kåre Lilleholt, 'A Half-built House? The New Consumer Sales Directive Assessed as Contract Law' (2019) Juridica International 3. - DOI: https://doi.org/10.12697/ji.2019.28.01; see Klaus Tonner (n 27) 367. This is critical in particular with regard to the sales directive. Ivo Bach, 'Neue Richtlinien zum Verbrauchsgüterkauf und zu Verbraucherverträgen über digitale Inhalte' (2019) NJW 1711.

42 Article 10 (3) SGD. True, this is also possible under art 11(2) DCD and - pertaining to hidden defects - art 3 (10), recital 12 sentence 3.

43 Article 3 (7) SGD. On the liability periods in cases of smart goods, see also Carvalho (n 21) 199.

44 On this, see Ignace Claeys and Jonas Vancoillie, 'Remedies, Modifications of Digital Content and Right to Terminate LongTerm Digital Content Contracts' in Ignace Claeys and E Terryn (eds), Digital Content and Distance Sales (Intersentia 2017) 220. - DOI: https://doi.org/10.1017/9781780686035.

45 Article 11(2) SGD.

46 Article 11(3) SGD. Here the crucial question is how to qualify one-off supply of digital content and the inter-connected digital service. Is the operating system of a smartphone or a smart TV embedded digital content and hence a one-off contract (art 11(2) SGD) or a service providing for the continuous supply over a period of time (art 11(3) SGD)? I would argue for the first, but in some cases delineation becomes very complicated. Smart TV software is i considered continuous supply of digital content or digital service by Jasper Vereecken, Jarich Werbrouck, Goods with Embedded Software: Consumer Protection 2.0 in Times of Digital Content? (2019) 30 Indiana International and Comparative Law Review 76. - DOI: https://doi. org/10.18060/25064.

47 Article 11(1) and recital 39 SGD. See also Staudenmayer (n 12) 2892. 
action is required by the seller so as to enable the consumer to use the digital content or digital service in accordance with the contract (for example, by providing a link or a download option). Here the crucial question is when the digital content is delivered to the consumer - i.e. when it has 'reached the sphere of the consumer and no further action is required by the seller in order to enable the consumer to use the digital content or digital service. ${ }^{*}{ }^{*} 8$ Has the operating system of a smart TV reached the sphere of the consumer when he takes home the new smart TV even if he still needs to accept the EULA later on? Is there still something required on the seller's part? Most probably no action is required of the seller anymore and, hence, the period of the reversed burden of proof commences upon the delivery of the good. However, it is important to assess the whole set-up process for the smart good to determine whether the correct set-up really depends only upon the consumer (and his Internet connection etc.) or there is indeed action required on the seller's part. If the seller ${ }^{*} 49$ still has to, for instance, activate an account, then the delivery happens only at that point, also for purposes of considering scratches on the TV screen. ${ }^{*}{ }^{*}$ All in all, this means that if the set-up process of a smart good requires some action from the seller, then the seller runs a risk of the consumer postponing the set-up and hence also the delivery point and consequently the end to the reversed burden of proof as well as the liability period.

In sum, not only the general liability itself but also all the legal consequences described clearly incentivise sellers to exclude the digital elements from the sales contract. Through doing so, defects of digital elements would not entitle the consumer to a reduction in the price paid for the smart good or to terminate the contract. One might of course ask whether a defect in a digital element leading to the termination of a digital content contract may have some impact on the sales contract under national law if national law treats the sales contract and the inter-connected digital service contract as economically connected/linked contracts. However, as the DCD and SGD are maximum harmonisation directives ${ }^{*} 51$ and explicitly foresee only the liability of the digital content provider in these cases, there should be no room for possible additional liability of the seller under any national law concept. ${ }^{*}{ }^{5}$

Should, however, a seller be liable also for the digital elements of the good, lack of conformity of the digital element may entitle the consumer to a reduction in the contractual price 53 and even to termination of the whole sales contract, provided that this lack of conformity is not minor in the overall context of the sales contract. ${ }^{*} 54$ Before price reduction or termination the seller usually has a right to repair, although in certain serious cases immediate use of these remedies is possible.

\section{Contracts for the supply of both goods and digital services where the digital service forms the main subject of the contract}

Finally, the scope issue arises also in situations where a consumer contract provides for the supply of both goods and digital services and where the digital service is the principal subject of the contract. An example could be a contract under which a telecom provider promises to supply both a very inexpensive TV box (a tangible good) and digital-TV service. ${ }^{*} 55$ In such a contract, the digital-TV service is clearly the principal subject of the contract. Were we to apply the test developed by the CJEU in the Schottelius case, the whole contract would fall outside the scope of the directive. In the Schottelius case, a renovation contract for a swimming pool that included the delivery of a water pump was qualified as not being even partly covered

48 As stated in recital 39 SGD.

49 The directive does not clarify whether the notion of seller here also includes the digital service provider. The language used in recital 39 SGD stressing that 'the seller should also make the digital content or digital service available or accessible to the consumer' suggests an affirmative answer.

50 If the seller also provides installation, then the relevant point of time is the end of the installation. See Staudenmayer (n 12) 2893.

51 At least in principle; see Article 4 DCD and Article 4 SGD.

52 See Sein and Spindler (n 7) 19.

53 Article 13(4) and 15 SGD.

54 Article 13(5) SGD.

55 The digital television service clearly falls within the scope of the DCD; see recital 31 DCD. 
by the 1999/44 consumer sales directive but, rather, subject to national contract law, because the sale of the goods was merely ancillary in comparison with that provision of services. ${ }^{*}{ }^{6}$ However, if we look at recital 33 of the DCD, it explicitly addresses situations where digital television service and equipment are offered under the same contract:

Digital content or digital services are often combined with the provision of goods or other services and offered to the consumer within the same contract comprising a bundle of different elements, such as the provision of digital television and the purchase of electronic equipment. In such cases, the contract between the consumer and the trader includes elements of a contract for the supply of digital content or a digital service, but also elements of other contract types, such as sale of goods or services contracts. This Directive should only apply to the elements of the overall contract that consist of the supply of digital content or digital services. The other elements of the contract should be governed by the rules applicable to those contracts under national law or, as applicable, other Union law governing a specific sector or subject matter.

Hence, in cases where the contract covers the supply of both goods and digital services and where the digital service forms the main subject of the contract, both directives are applicable: the digital-TV service part of the contract is governed by the DCD and the TV-box part by the new Sales of Goods Directive notwithstanding the fact that the sale of a TV box can be seen as being merely ancillary when compared with the digitalTV service. Consequently, the test developed in the Schottelius case ${ }^{*} 57$ cannot be applied anymore to cases where one part of the contract consists of the supply of digital content or digital services.

\section{Conclusions}

The adoption of the new consumer contract law package in 2019 has aroused a question about the delimitation of the scopes of the directives: are 'goods with digital elements' within the scope of the Digital Content Directive or the new Sales of Goods Directive, or even both? As a starting point, the rules of the directives create a legal presumption that the seller of the smart good is liable not only for the tangible good and embedded digital software but also for the inter-connected digital services. This should be so even if the consumer concludes an additional licensing contract with the digital service provider in order to benefit from the digital service. However, a deeper look into the directives shows that there is much room left for party autonomy, with a consequence that exactly the opposite might become true in practice. The recitals of the directives show that express agreement in sales contract may limit the liability of the seller even for the operating system of a smart good and thus override the reasonable consumer expectations. To avoid such a result, the courts should set high standards for such 'express agreement' between the consumer and the seller.

The situation becomes even more complicated for the consumer when the 'digital element' of the good is free and open-source software. In these cases, the 'separately bought' digital content does not even fall within the scope of the DCD, with the result that the seller is not liable for the digital content under the SGD and the digital content provider is not liable for it under the DCD. The consumer is then left without any remedies under the directives. All in all, the sellers of goods with digital elements are clearly incentivised to exclude the digital elements from the sales contract. By doing so, they may avoid liability for the digital elements; ie the consumer would not be able to claim a reduction in the price paid for the smart good or terminate the sales contract if there is a defect in the digital content or services. As the new directives are maximum harmonising and explicitly foresee only the liability of the digital content provider in these cases, the seller cannot be held liable under national law (e.g. under the concept of linked contracts) either. Therefore, the new contract law package does not raise the level of consumer protection as much as it initially seems to do.

Finally, the scope issue arises also in situations where a consumer contract provides for the supply of both goods and digital services and where the digital service is the principal subject of the contract. Recital 33 of the DCD suggests that the test developed in the Schottelius case cannot be applied in these cases, with the result that the SGD is applicable to the tangible part even if it can be seen as being merely ancillary relative to the digital services.

56 Case C-247/16, Heike Schottelius $v$ Falk Seifert [2017] 44-46.

57 See Carvalho (n 43). Further on this, see Lorenzo Bertino, 'Service Contracts and EU Directive 1999/44 on Consumer Sales' (2018) EuCML 211ff. 